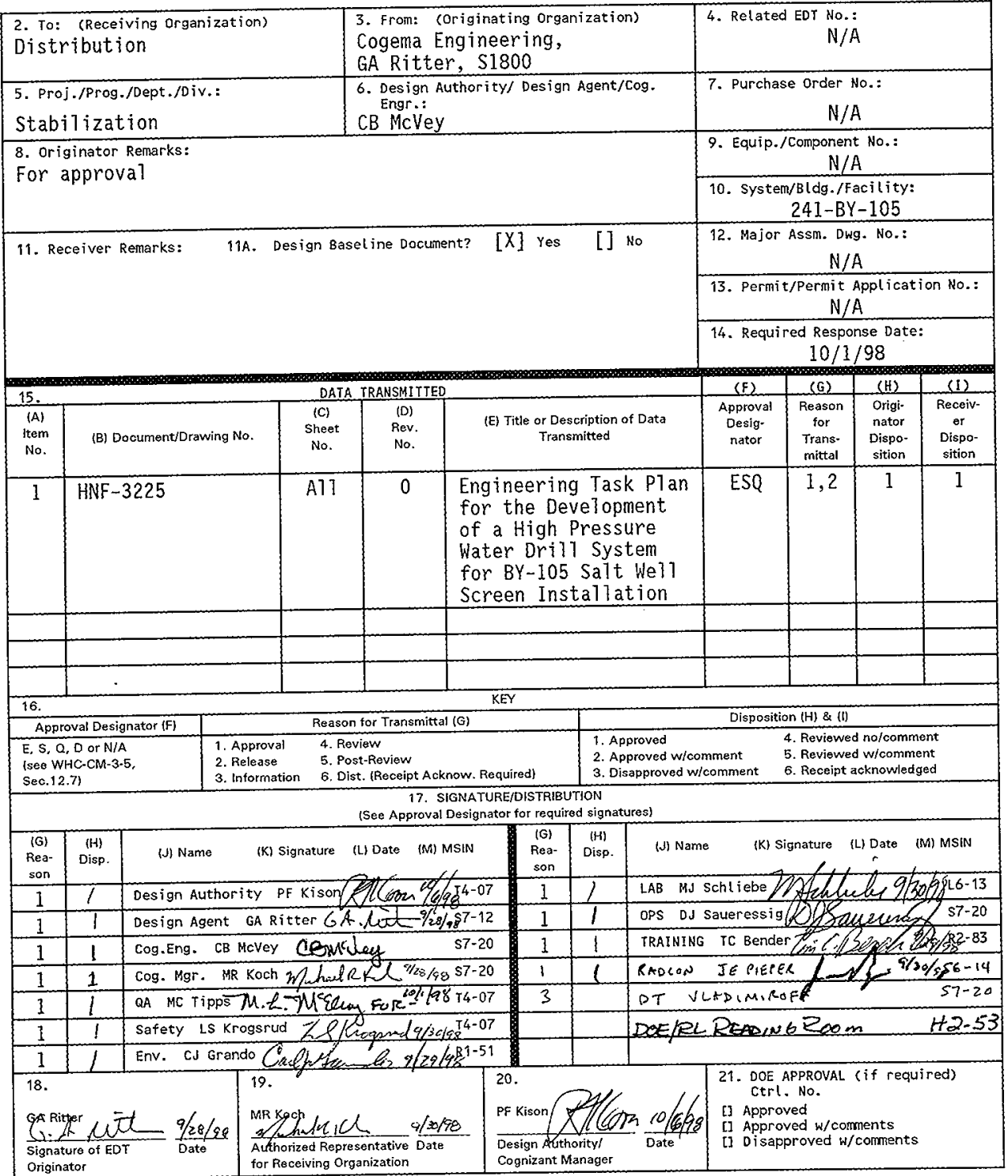




\section{Engineering Task Plan for the Development of a High Pressure Water Drill System for BY-105 Saltwell Screen Installation}

Glenn A. Ritter

Cogema Engineering, Richland, WA 99352

U.S. Department of Energy Contract DE-AC06-96RL13200

EDT/ECN: 623331

UC: 2030

Org Code: $\$ 1800$

Charge Code: 103338

B\&R Code: EW3120071

Total Pages: 37

Key Words: stabilization, saltwel? screen, water drill, BY-105

Abstract: This engineering task plan identifies the activities required for developing an ultra high pressure water drill system for installation of a saltwell screen in Tank BY-105. A water dri11 system is needed to bore through the hard waste material in this tank because of the addition of Portland cement in the 1960 s and/or 1970s. The activities identified in this plan include the design, procurement, and qualification testing of the water drill along with readiness preparations including developing operating procedures, training Operations personnel, and conducting an assessment of readiness.

TRADEMARK DISCLAIMER. Reference herein to any specific commercial product, process, or service by trade name, trademark, manufacturer, or otherwise, does not necessarily constitute or imply its endorsement, recommendation, or favoring by the United States Government or any agency thereof or its contractors or subcontractors.

Printed in the United States of America. To obtain copies of this document, contact: Document Control Services, P.O. Box 950, Mailstop H6-08, Richland WA 99352, Phone (509) 372-2420;

Fax (509) 376-4989.
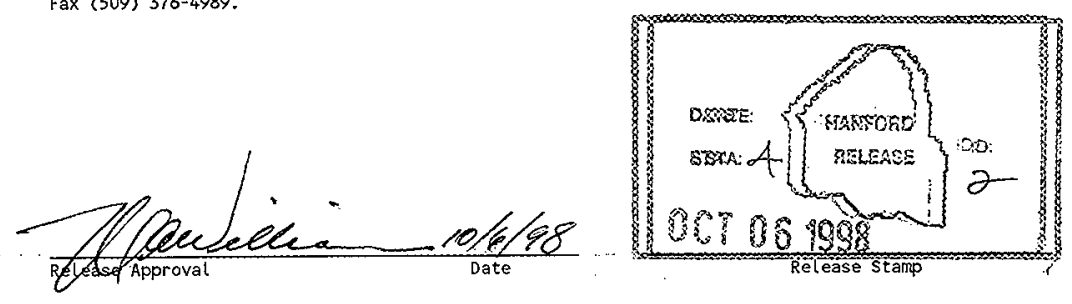

\section{Approved for Public Release}




\section{CONTENTS}

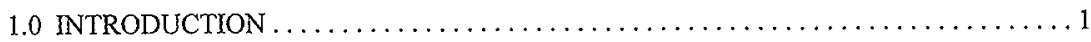

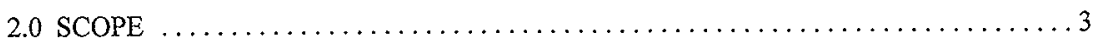

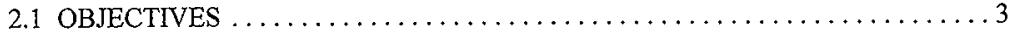

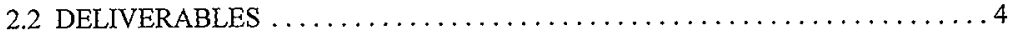

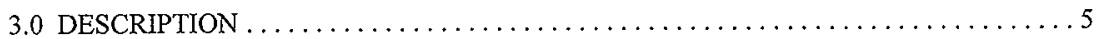

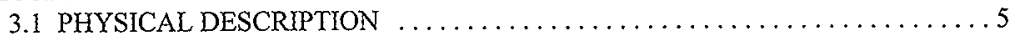

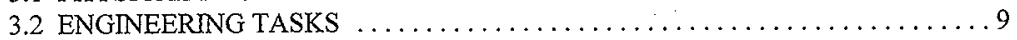

3.3 DESIGN VERIFICATION AND TESTING $\ldots \ldots \ldots \ldots \ldots \ldots \ldots \ldots \ldots \ldots$

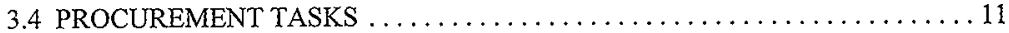

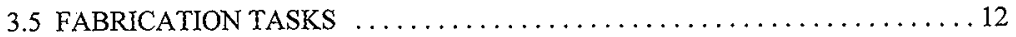

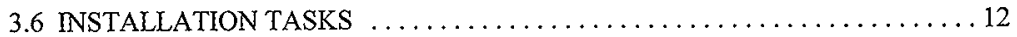

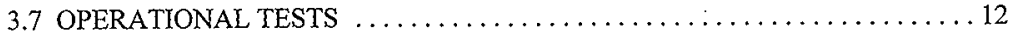

3.8 ACCEPTANCE FOR BENEFICIAL USE $\ldots \ldots \ldots \ldots \ldots \ldots \ldots \ldots \ldots$

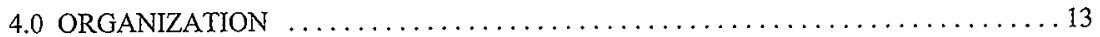

4.1 CHARACTERIZATION EQUIPMENT ENGINEERING $\ldots \ldots \ldots \ldots \ldots \ldots \ldots 13$

4.2 TWRS INTERIM STABILIZATION ENGINEERING $\ldots \ldots \ldots \ldots \ldots \ldots \ldots 14$

4.3 TWRS OPERATIONS AND PROJECT SAFETY SUPPORT $\ldots \ldots \ldots \ldots \ldots 15$

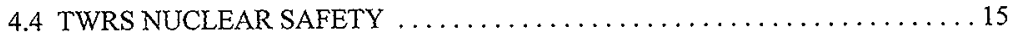

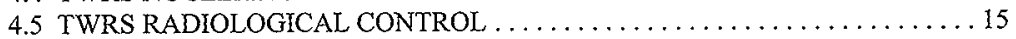

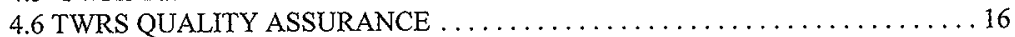

4.7 TWRS ENVIRONMENTAL PERMITS/POLICY $\ldots \ldots \ldots \ldots \ldots \ldots \ldots \ldots \ldots$

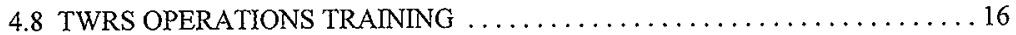

4.9 NUMATEC HANFORD COMPANY EQUIPMENT DEVELOPMENT AND

TESTING LABORATORIES $(305 \& 306$ E FACILITIES) $\ldots \ldots \ldots \ldots \ldots \ldots 17$

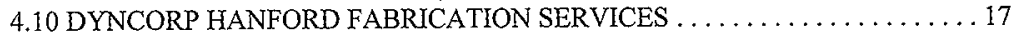

4.11 DYNCORP HANFORD CRANE \& RIGGING SERVICES . . . . . . . . . 17

4.12 TWRS INTERIM STABILIZATION OPERATIONS $\ldots \ldots \ldots \ldots \ldots \ldots \ldots 18$

4.13 TWRS PRODUCTION CONTROL $\ldots \ldots \ldots \ldots \ldots \ldots \ldots \ldots \ldots \ldots \ldots \ldots$

5.0 SCHEDULE AND COST ESTIMATE $\ldots \ldots \ldots \ldots \ldots \ldots \ldots \ldots \ldots \ldots \ldots \ldots \ldots \ldots \ldots \ldots$

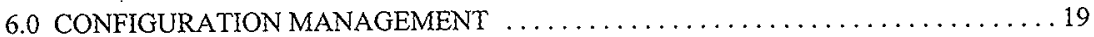

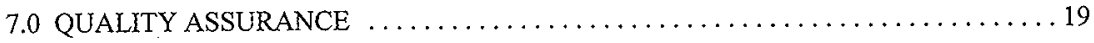

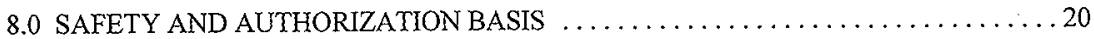

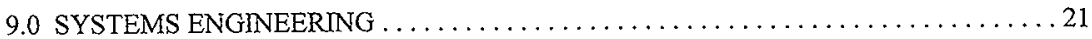


HNF-3225 Rev. 0

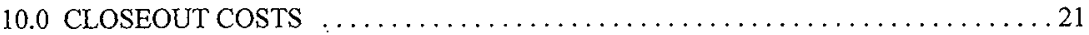

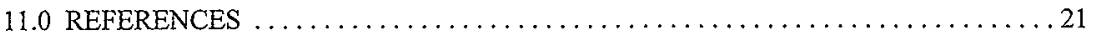

APPENDIX A - ACCEPTANCE FOR BENEFICIAL USE FORM $\ldots \ldots \ldots \ldots \ldots \ldots$ A-1 APPENDIX B - SCHEDULE AND COST ESTIMATE $\ldots \ldots \ldots \ldots \ldots \ldots \ldots \ldots \ldots$ B-1 
HNF-3225 Rev. 0

\section{ENGINEERING TASK PLAN \\ FOR THE DEVELOPMENT OF A HIGH PRESSURE WATER DRILL SYSTEM FOR BY-105 SALTWELL SCREEN INSTALLATION}

\subsection{INTRODUCTION}

The Tank Waste Remediation System (TWRS) Program requires stabilization of singleshell waste storage tanks (SSTs) in the BY Tank Farm. The stabilization activities include the installation of a saltwell screen through one of the SST risers, into which a submersible jet pump can be installed to extract pumpable liquid that drains through the screen. In 1995, the TWRS Interim Stabilization Project attempted to install a saltwell pump into an existing saltwell screen in tank BY-105. In attempting to clear the screen with a water lance, a very hard layer of material near the surface of the waste was discovered. Subsequent investigation identified the addition of Portland cement in the mid 1960s and/or 1970s. Recent attempts to core sample also encountered relatively hard material near the waste surface. Although "push-mode" core sampling was not successful in penetrating the hard waste, "rotary-mode" core sampling was successful in drilling through the waste with less effort than expected.

Several alternatives for penetrating the hard waste material for saltwell installation have been identified and several of these alternatives are being pursued by other TWRS organizations. One option is to core drill multiple holes in the waste through the riser where the saltwell screen will be installed using an existing rotary mode core sampling system (RMCSS). Following drilling, an expansive grout mixture could be poured into the holes to break up the hard waste material and/or the existing Hiline high pressure ( $3000 \mathrm{psi}$ ) water lance could be used. A second option would be to just use an existing high pressure lance without drilling multiple holes because the waste may not be as hard as expected. If an expansive grout were used to break up the waste, some type of high pressure water lance should be used in addition to further break up and carry the waste cuttings away to provide a hole for saltwell installation. It is unlikely that the weight of the saltwell screen alone would be sufficient for pushing through and displacing the broken up waste, because push mode core sampling was not successful. A disadvantage for using an existing water lance is the amount of water that may be required to install the saltwell screen. For these options to be successful, the strength of the waste material must be much less than Portland cement. Scoping tests, as described in Section 3.3.2, are planned for comparing the strength/hardness of the BY-105 waste with Portland cement by core drilling various mixtures of cement with the test drill rig. These tests should provide very useful information for evaluating what method should be used.

The third method is to use an existing ultra-high pressure (UHP) lance (e.g., the lance used for temperature/vapor probe [TVP] installation) to break up the hard waste material that is in the existing saltwell screen installed in riser 13B. This method has proven very successful for the installation of TVPs in tank farm waste tanks. This lance bores a nominal $10 \mathrm{~cm}$ (4 in.) diameter hole and could be used to make several "stabs" through the waste inside the saltwell screen to create a large enough hole for installing a saltwell pump. The success of this method 
depends on how badly "clogged" the saltwell screen is with hardened waste. If the lancing were successful and a saltwell pump could be installed, the interstitial liquid may not drain very well through the existing saltwell screen. In addition, the waste particulates inside the saltwell screen could be damaging to the pump internals. The other uncertainty with this method is whether or not the lance will break up the waste into fine enough particles such that it will be displaced through the screen or around the pump assembly when the pump is installed.

The fourth option is to use the existing UHP lance that was procured for saltwell screen installation. Preliminary testing has demonstrated that this lance is capable of breaking up Portland cement, although the penetration rates were much less than desired. The cutting capability of this water drill was limited by the flow capacity of the available high pressure intensifier, which was just under $11.3 \mathrm{liter} / \mathrm{min}$ ( $3 \mathrm{gpm})$. In addition, the wheels, which were installed on the bottom of the drill to provide a minimum offset from the tank bottom, did not rotate very easily on the cement surface and caused the drill to wander somewhat during the preliminary testing. Also, the flow through the high pressure nozzles was insufficient to evacuate the cuttings and a separate water line was needed to flush the material away from the cutting surface. The primary disadvantage of using this device is the length of time and volume of water that may be required to bore a hole through the hard waste. If the waste is really as hard as Portland cement, several shifts of effort and thousands of gallons water could be required. If the scoping tests indicate that the waste is much softer than Portland cement, using this tool may be a good alternative. This tool may also be a good option if the BY-105 core data shows that the hard waste layer is only a few inches thick.

The fifth and final option is to develop a new larger diameter UHP water lance/drill to penetrate the hard waste material. Additional cutting capability can be obtained by the addition of an abrasive garnet to the high pressure water stream. An abrasive water jet has been proven to easily cut through cement along with many other materials, such as steel. Use of an abrasive water jet may provide too much cutting capability and safety concerns associated with penetrating the tank bottom would have to be evaluated. In addition, the flammable gas concerns associated with spark generation from the abrasive garnet would have to be addressed. The alternatives are summarized as follows.

1a) Drill multiple holes using RMCSS

1b) Drill multiple holes and use expansive grout

1c) Drill multiple holes and use existing high pressure lance

1d) Drill multiple holes, use expansive grout, and existing high pressure lance

2) Use the existing Hiline high pressure lance

3) Use an existing TVP UHP lance inside the existing saltwell screen

4) Use the existing UHP water drill procured for saltwell screen installation

5a) Develop and use new UHP water drill without an abrasive garnet

5b) Develop and use new UHP water drill with abrasive garnet 
Clearly, the normal operation of low pressure water lancing for saltwell installation was not successful in penetrating through the tank waste in BY-105 during the original attempt. Another method must be used to allow insertion of a new saltwell screen in an adjacent riser or to allow installation/operation of a saltwell pump in the existing saltwell screen. Option 5a was determined to be the method with the highest probability of success without creating substantial safety concerns. The other methods may be pursued concurrently with this option and if the other methods prove successful, a new water drill will not be required. This engineering task plan (ETP) focuses on the activities required for developing and testing a UHP water drill system. The results of the scoping tests might indicate a need to reevaluate the method that is most appropriate for penetrating the BY-105 waste. If a method is selected that is different than the baseline method described in this ETP, then this ETP will be revised accordingly. This task also involves readiness preparations including developing operating procedures, training TWRS Operations personnel, and conducting an assessment of readiness, as required. This ETP does not address revising the Authorization Basis $(\mathrm{AB})$ and assumes that this technology will not require an $\mathrm{AB}$ amendment. However, if it is determined during the performance of this task that an $A B$ amendment is required, the $\mathrm{AB}$ implications will be identified for resolution and this ETP will be revised.

\subsection{SCOPE}

\subsection{OBJECTIVES}

The primary objectives of this development activity are as follows:

- Provide all necessary engineering and staff to support the planning, design, fabrication, procurement, testing, and implementation of the water drill system;

- Maximize use of existing designs, equipment, and procedures to reduce development time and cost;

- Design the system to minimize exposure and contamination to operations personnel and the environment;

- Coordinate with all user/user support groups to obtain concurrence on the design;

- Obtain all necessary permits and safety documentation required to authorize operation of the water drill system on the Hanford site;

- Provide operating procedures/work instructions and support training of operations staff. 
HNF-3225 Rev. 0

\subsection{DELIVERABLES}

The following deliverables will be provided:

\section{DOCUMENTATION}

- This task plan including the functions and requirements for the water drill system;

- Unreviewed Safety Question (USQ) screening/determination, Hazards Assessment, Flammable Gas Equipment Advisory Board (FGEAB) report, Safety Equipment List (SEL), Commercial Grade Item (CGI) forms, and other safety documentation, as required;

- Procurement specification for the water drill system;

- As-built engineering drawings, sketches, and vendor drawings along with applicable vendor information;

- Qualification test plan/procedure and test report to document the procedures and results of qualification testing of the system;

- Installation/operation work instructions for the water drill system;

- Acceptance for Beneficial Use (ABU) form documenting turnover and acceptance to TWRS Operations.

\section{HARDWARE}

- One (1) each high-pressure water jet drill assembly for installation on the bottom of a deployment device or saltwell screen assembly;

- One (1) deployment device, as required, for deployment of water jet cutting system into tank BY-105. May not be required if water jet drill can be adapted to the bottom of a saltwell screen;

- Tank interface equipment including spray washer for decontamination, and sealing mechanism to maintain containment during deployment/operation of water drill system, as required;

- Waste box or container for regulated UHP water lance storage, as required. 


\subsection{DESCRIPTION}

\subsection{PHYSICAL DESCRIPTION}

The current conceptual design for the high pressure water jet cutting system consists of four major components: water jet drill head, high pressure intensifier system, deployment device, and tank interface. A conceptual sketch of the system is shown in Figure 1. The water drill will be vendor designed/fabricated and will consist of a series of high pressure water jets/nozzles arranged to cut a nominal $30.5 \mathrm{~cm}$ (12 in.) diameter hole (or $25 \mathrm{~cm}$ [10 in.] diameter if a $20 \mathrm{~cm}$ [8 in.] saltwell screen is used) through the hard waste material. The cutting head (or hole) will be larger than the deployment device support pipe (or saltwell screen) to allow an annular space for the cuttings to be flushed away from the cutting surface. A separate flush line may be needed to the face of the cutting head for enhanced cuttings removal. Depending on the number of nozzles on the cutting head, the water drill may need to be rotated to some degree during deployment/operation to obtain the full circular cut. The number of nozzles is limited by the flow capacity of high pressure water from the intensifier system. A mechanical stop may also be required on the cutting head to prevent tank damage in case the water drill were to contact the tank bottom. The stop would limit the distance between the nozzles and the cutting surface.

The high pressure intensifier system supplies water at pressures up to $350 \mathrm{MPa}$ $(50,000 \mathrm{psi})$ to the water drill system. The current plan is to rent/lease an intensifier system from the vendor that provides the water drill, because an intensifier system may not be available on the Hanford site. The deployment device will be a long-length pipe (nominally 10 in. schedule 40) with piping to supply high pressure water and possibly flush water to the drill head. If the water drill must be rotated continuously during deployment, swivel pipe fittings will be required at the top of the deployment device. As mentioned previously, the deployment device may be a modified saltwell screen depending on how close the saltwell screen must be located to the tank bottom. Using a modified saltwell screen instead of a custom deployment device could represent a significant savings both in design and installation/operation costs, as well as retrieval/disposal costs. The tank interface equipment consists of a spray washer for decontaminating the water drill upon removal. If a modified saltwell screen is used as the deployment device, it will not be removed under normal operating conditions, and the spray washer would only be used on a contingency basis. The spray washer will operate on nominal $6.9-20.7 \mathrm{MPa}(1000-3000 \mathrm{psi})$ water from a source such as a commercial high pressure washer. The tank interface equipment may also include a sealing mechanism for providing containment during installation/removal and will be compatible with existing methods for saltwell installation.

\subsubsection{Functions and Requirements}

The water drill system must satisfy the functions and requirements listed in the following sections. 


\subsubsection{Performance Requirements}

- The diameter of the hole that is cut by the water drill system shall be at least $2.5 \mathrm{~cm}(1 \mathrm{in}$.) larger than the outside diameter of the saltwell screen. For $21.9 \mathrm{~cm}$ ( $8.625 \mathrm{in}$.) and $27.3 \mathrm{~cm}(10.75 \mathrm{in}$.) outside diameter saltwell screens, the holes shall be at least $24.4 \mathrm{~cm}(9.625 \mathrm{in}$.) and $29.8 \mathrm{~cm}$ (11.75 in.), respectively. Depending on nozzle configuration, the drill may need to be rotated manually back and forth through some angle to obtain the full circular cut.

- The cutting rate through material of strength equal to 28-day cured Portland cement/water mixture shall be a minimum of $2.5 \mathrm{~cm} / \mathrm{min}$ ( $1 \mathrm{in} . / \mathrm{min}$ ) using no more than $280 \mathrm{liter} / \mathrm{min}$ (70 gpm) water (includes any flush water, if required), which is a limit imposed from the Notice of Construction (NOC). Flow rates much lower than this are expected. In addition, the cutting rate should be maximized, with cutting rates greater than $5 \mathrm{~cm} / \mathrm{min}$ ( $2 \mathrm{in} . / \mathrm{min})$ desirable.

- Total water usage (UHP, flush water, and any spray wash water) shall be minimized. It is desirable to keep total water usage below 1890 liters (500 gallons), which is an administrative limit, and management authorization is required to exceed this limit.

- Testing shall be performed by drilling through Portland cement with a minimum depth of $0.9 \mathrm{~m}(3 \mathrm{ft})$ to demonstrate that cuttings will be sufficiently evacuated from the cutting surface and will not impede the cutting action. A separate flush line to the drill head may be needed to add water intermittently or continuously for removing the cuttings.

- A spray washer decontamination system will be developed to reduce the radioactive contamination levels of the deployment device to allowable levels when the device is withdrawn from the tank. The spray washer shall operate on a nominal $6.9-20.7 \mathrm{MPa}(1000-3000 \mathrm{psi})$ water source from a commercial high pressure washer. The spray washer may need to be a split piece design if a saltwell screen is used as the deployment device, because the screen will not be removed.

- The deployment device with drill head and spray washer shall be reusable and portable (this requirement does not apply if the drill head is adapted to a saltwell screen).

- The operating life of the system shall be no less than 10 hours before servicing is needed. Serviceable items shall allow for easy field replacement. 
HNF-3225 Rev. 0

Figure 1. Conceptual Sketch of the High Pressure Water Drill System

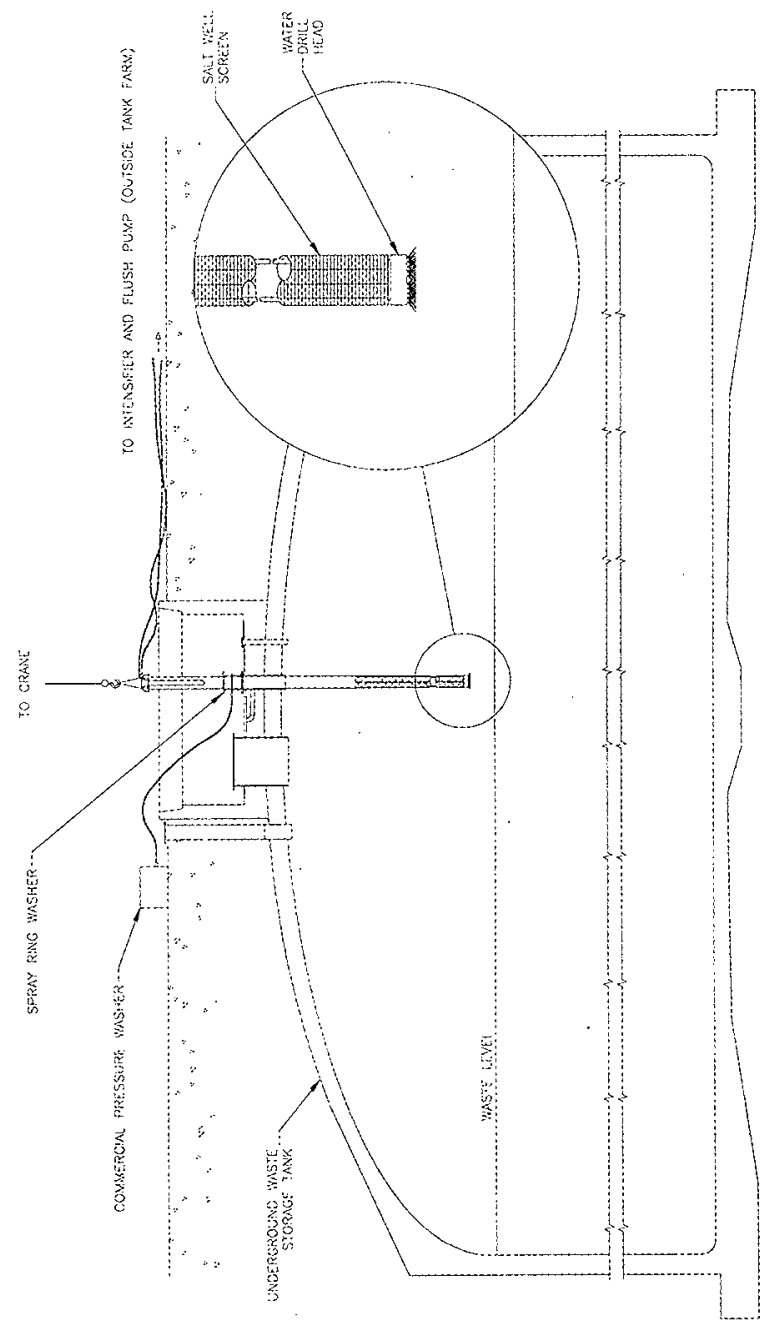




\subsubsection{Mechanical and Material Requirements}

- An administrative control that limits the lance operating pressure near the tank bottom is planned for system operation to prevent damage to the tank bottom. Testing shall be performed to demonstrate that the surface erosion on ASTM A36 carbon steel plate (with surface scale removed and bare "white" metal exposed) is no greater than $0.025 \mathrm{~cm}(0.010 \mathrm{in}$.) in five minutes with the drill head (or mechanical stop, if required) in contact with the plate using the drill system at these lower limiting operating conditions (flow and pressure).

- Drill head and deployment device shall be constructed of material that is compatible with the tank waste, which has a $\mathrm{pH}$ level up to 12 . Use of stainless steel for metal components is preferred.

- None of the equipment inserted into the tank shall be spark generating. The deployment device will be grounded to the tank riser during installation/operation/removal.

- The water drili system shall function with a high pressure intensifier capable of pressures ranging up to $345 \mathrm{MPa}(50,000 \mathrm{psi})$.

- Overall length of the drill head and deployment device will be approximately

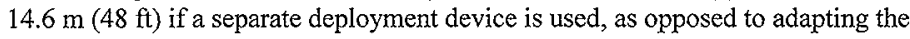
drill head to a saltwell screen

- Lifting bail(s) shall be provided at the top end of the deployment device to allow a pick by an overhead crane. The deployment device shall have sufficient bending strength to allow uprighting from horizontal to vertical by lifting from only the top end.

- The in-tank equipment shall be decontaminable and shall be contoured to allow "snag free" removal from a riser and be self-draining. Welds, crevices, and recesses shall be smooth and non-sealed joints shall be minimized. Internal recesses that are not easily accessible for decontamination shall be minimized or eliminated.

\subsubsection{Safety}

- System shall make use of methods to minimize exposure of the operators and staff to all hazards, striving for exposure being as low as reasonably achievable (ALARA).

- Radiation shine through a tank riser is a hazard to personnel. The drill system configuration shall minimize the need for personnel to operate the system near the tank riser. 
HNF-3225 Rev. 0

- System operation shall be in compliance with riser and tank load limits.

- Installation/operation/removal method of the water drill system shall minimize the possibility of an unfiltered radioactive material release to the environment.

- System shall operate safely in an environment potentially containing flammable gases.

- Installation/operation of the water drill system shall comply with controls specified in the $\mathrm{AB}$.

\subsubsection{Interfaces}

- The water drill and deployment device shall be installable through a $29.2 \mathrm{~cm}$ (11.5 in.) inside diameter riser that is up to $4.6 \mathrm{~m}$ (15 ft) long.

- Interfacing the high pressure pumps and intensifiers with the existing support trailer, which includes a generator, water tank, and high pressure hoses, shall be considered.

\subsection{ENGINEERING TASKS}

The engineering tasks to be performed as part of this activity are as follows:

- Preparing this task plan

- Defining and documenting the functions and requirements for the water drill system in this task plan

- Preparing a USQ screening and USQ determination, as required

- Performing and documenting a Hazards Assessment, as required

- Determining the safety classification for the Systems, Structures, and Components (SSCs) and preparing/updating the SEL, as required

- Preparing CGI forms for the water drill system, as required

- Preparing a FGEAB review package and presentation, as required

- Preparing engineering sketches for the deployment device and tank interface equipment fabrication

- Performing design reviews and resolving design review comments

- Providing technical direction for fabrication of the water drill system

- Preparing as-built engineering drawings of the water drill system components

- Preparing a procurement specification for the water drill head and intensifier system

- Providing oversight and technical direction for the vendor design, fabrication, and testing of the water drill

- Preparing a vendor information (VI) file for the water drill system

- Preparing a test plan/procedure, and test report to document the methods and 


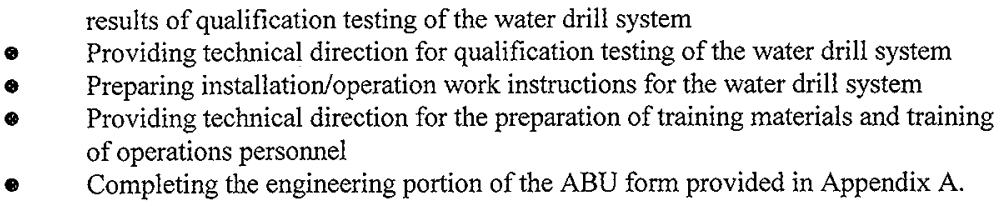

The responsible personnel and organizations for the tasks listed above along with other responsibilities are identified in Section 4.0.

\subsection{DESIGN VERIFICATION AND TESTING}

\subsubsection{Design Reviews \& Inspections}

Design verification of the water drill system shall be performed in accordance with HNFPRO-445, Design Verification Requirements (HNF 1997l). Two design reviews are planned: an initial review prior to fabrication of components, and a final design review following functional testing, after any required design changes have been incorporated. The initial design review may be split into two separate reviews depending on when the vendor design is ready for review. These design reviews will be formal reviews if the water drill system or some of its components are designated as Safety Class SSCs based on the Hazards Assessment. Otherwise, other design reviews methods such as independent reviews may be used.

Included in these design reviews will be a review from the Radiological Control organization in accordance with HNF-PRO-1622, Radiological Design Review Process (HNF 1998). The purpose of these design reviews will be to ensure that appropriate methods and considerations are integrated into the design to maintain occupational exposures ALARA during the installation/operation/removal of the UHP water drill and saltwell screen.

A Quality Assurance (QA) inspection plan shall be prepared in accordance with HNFPRO-268, Control of Purchased Items and Services (HNF 1997f), to verify that the vendor's water drill head design meets the requirements identified in the procurement specification (which will include applicable design requirements from this ETP). This inspection will consist of a source inspection and/or receipt inspection of the vendor fabricated water drill head. QA witness of water drill functional testing at the vendor's facility may be included as part of the QA inspection plan.

\subsubsection{Testing}

Initial scoping tests are planned to help compare the strength and hardness of the BY-105 waste with known material, i.e., Portland cement. These tests will consist of core drilling various mixtures of Portland cement to accomplish two basic objectives. The first objective is to compare the down force and penetration rate data obtained from core drilling BY-105 waste to load and penetration rate data for different mixtures of Portland cement. The mixtures planned consist of 
using $25 \%, 50 \%, 100 \%, 150 \%$, and $200 \%$ of the optimal amount of water. Because the cement was put into BY-105 in a dry condition, it was most likely not well mixed with the liquid waste present in the tank, such that the optimal water mixture ratio was not obtained. This process most likely resulted in a much weaker cement mixture.

If testing shows that the BY-105 waste is much softer than high strength Portland cement, then the second objective will be to choose a cement mixture that is comparable to the strength characteristics of the BY-105 waste so that a more realistic simulant can be used for water drill functional tests. A "best case" and a "worst case" simulant would be used for the tests to allow design decisions to be based on more realistic conditions. Depending on the results of these scoping tests, it may be necessary to reevaluate the need for developing a new UHP water drill. These tests may indicate that an existing water lance may be adequate for penetrating the hard waste in tank BY-105.

Qualification testing is the final design verification method appropriate for the water drill system. Qualification testing shall be performed in accordance with HNF-PRO-446, Testing Requirements (HNF 1997m). A test plan/procedure will be prepared to identify the requirements and methods for qualification testing followed by a test report to summarize the results.

\subsection{PROCUREMENT TASKS}

Procurement activities will be coordinated by Cogema personnel with approval from Lockheed Martin Fanford Company (LMHC) for major purchases. Procurement of safety class equipment, if required, shall be performed in accordance with FNF-PRO-447, Procurement of Safety Structures, Systems, and Components and Management of Spares (HNF 1997n). Any CGI forms required to support procurement activities will be prepared in accordance with HNFIP-0842, Volume IV, Section 3.11, "Replacement Item Evaluation, Commercial Grade Item Dedication and Upgrade" (LMHC 1998a).

A procurement specification will be prepared in accordance with HNF-PRO-241, Engineering Specification Requirements (HNF 1997c), for design, fabrication, and functional testing of the water drill system. The procurement specification will also include the rental/lease of the high pressure water intensifier system, as required.

All materials and components for safety SSCs shall be procured in accordance with HNFPRO-447 (FNF 1997n). Material certifications, in accordance with the applicable ASTM/ASME material standards, shall be required for safety class purchased raw material and weld filler metal. Material certifications shall be traceable to the material heat or lot number. Traceability to the material certifications shall be maintained during fabrication as noted by the associated drawing, sketch, or specification. QA/QC inspection will be performed on safety class raw material procurements to assure identification and traceability in accordance with HNF-PRO-268 (HNF 1997f). 


\subsection{FABRICATION TASKS}

Fabrication of components shall meet the requirements specified on the drawings and this task plan. Design and fabrication of the water drill system shall be in accordance with HNF-PRO442, Development Control Requirements (HNF 1997j). The requirements to be followed are those for hardware with facility-use potential.

Drawings, sketches, and specifications shall be identified as "Development Control" per ENF-PRO-442. Two complete independent sets of these fabrication drawings shall be maintained with identical information, and updated on a daily basis (if drawing changes are required). One set is to be in the responsible engineer's possession and one set is to be with the fabrication package. Changes, additions, or deletions to development control drawings, sketches, or specifications shall be controlled either by marking the change in red ink or by preparing additional pages or sketches and identifying traceability to the affected drawing, sketch, or specification. A logbook of drawing changes and their location is to be maintained with the drawings. For all drawing modifications, the affected area shall be clouded in red, signed, and dated by the responsible engineer or his designee.

At the end of fabrication, all development control changes shall be incorporated into the appropriate engineering documents. Engineering drawings shall be prepared and released as $H$-series drawings in accordance with HNF-PRO-242, Engineering Drawing Requirements (HNF 1997d). Engineering specifications shall be prepared and released in accordance with HNFPRO-241 (HNF 1997c). All subsequent changes to released drawings and documents shall be controlled using the engineering change notice ( $E C N)$ process in accordance with HNF-PRO-440, Engineering Document Change Control Requirements (HNF 1997i).

\subsection{INSTALLATION TASKS}

All installation activities associated with this task plan including development of installation procedures/work instructions and work packages will be managed and performed by LMHC personnel or their designates.

\subsection{OPERATIONAL TESTS}

Following fabrication of the water drill system components, a qualification test will be performed to verify that the system meets the design requirements. The final part of this qualification test will include an operability test in a non-radioactive environment conducted and evaluated by TWRS Operations personnel. The operability test will simulate operation/instaliation of the water drill system into a waste tank through a mock-up riser. This test will also be used to evaluate the installation procedures/work package by stepping through the procedures/work package during the water drill system operation. Currently, it is planned to have the operational test at the 277-W Fabrication Shop. However, if resources are limited, testing could be performed at the 305 or $306 \mathrm{E}$ Facility, where qualification testing will be performed. 


\subsection{ACCEPTANCE FOR BENEFICIAL USE}

The ABU process that will be used for this activity will conform with HNF-IP-0842, Volume IV, Section 3.12, "Acceptance of Structures, Systems, and Components for Beneficial Use" (LMHC 1998b). The actual ABU checklist/forms are provided in Appendix A. After completion of the testing of the water drill system, the $\mathrm{ABU}$ form will be completed and signed. The signed $\mathrm{ABU}$ form will be added to this task plan using the Engineering Change Notice (ECN) process in accordance with $\mathrm{HNF}-\mathrm{PRO}-440$. The ABU constitutes final acceptance of the system by TWRS Operations.

\subsection{ORGANIZATION}

The task descriptions and responsibilities are outlined in the following sections.

Signatures on the engineering data transmittal (EDT) for this document indicate agreement for the task responsibility, schedule, and estimated costs by the responsible organization.

\subsection{CHARACTERIZATION EQUIPMENT ENGINEERING}

Project Manager:

Lead Project Engineer:

ORG:
C. E. Hanson

G. A. Ritter

S7000

- Provide overall planning, scheduling, budgeting, and coordination of the project.

- Prepare this task plan including the functions and requirements specified in Section 3.1.1.

- Provide technical input for the preparation of the USQ screening/determination and the Hazards Assessment, as required.

- Prepare the CGI forms, FGEAB review package, and prepare/update the SEL, as required.

- Provide design/drafting support for the preparation of engineering drawings and sketches and coordinate design reviews.

- Coordinate and support the fabrication and procurement of all components of the water drill system including preparing a procurement specification, and providing technical oversight for vendor design, fabrication, and functional testing.

- Prepare a VI file to archive important vendor information. 
- Prepare the test plan/procedure and test report and provide technical direction for qualification testing of the water drill system.

- Support preparation of the installation/operation work instructions, training materials, and support training to Operations personnel.

- Prepare the $\mathrm{ABU}$ forms and coordinate approval of the ABU.

- Approve all engineering and safety documentation associated with the water drill system development.

\subsection{TWRS INTERIM STABILIZATION ENGINEERING}

$\begin{array}{ll}\text { Cognizant Manager: } & \text { M. R. Koch } \\ \text { Cognizant Engineer: } & \text { C. B. McVey } \\ \text { Design Authority: } & \text { P. F. Kison } \\ \text { ORG: } & 74920\end{array}$

- Provide funding and project management along with performing the Design Authority, Cognizant Engineer, and Cognizant Manager function.

- Provide technical direction for the preparation of this ETP including the functions and requirements and the $\mathrm{ABU}$ for the water drill system.

- Prepare the USQ screening and determination and provide technical direction for preparation of the Hazards Assessment, as required.

- Determine safety class designations for SSCs associated with the water drill system.

- Provide technical direction for the preparation of the SEL, CGI forms, and FGEAB review package, as required.

- Provide technical direction for the preparation of engineering drawings, sketches, and specifications (procurement specification), and perform design reviews.

- Provide technical direction for qualification testing of the water drill system.

- Review and approve the installation/operation work instructions, and support training to Operations personnel.

- Support the assessment of readiness, as required.

- Approve all engineering and safety documentation associated with the water drill system development. 


\subsection{TWRS OPERATIONS AND PROJECT SAFETY SUPPORT}
Manager:
C. E. Leach
Engineer:
TBD
ORG:
$2 \mathrm{~N} 140$

- Prepare the Hazards Assessment, as required, for the water drill system as it relates to installation, operation, and removal from tank BY-105.

\subsection{TWRS NUCLEAR SAFETY}
Manager:
W. T. Dixon
Engineer:
L. S. Krogsrud
ORG:
7B300

- Perform design reviews of water drill system design including vendor drill head design.

- Provide technical direction for the preparation of the USQ screening, USQ determination, and Hazards Assessment for the water drill system.

- Review and approve safety class designations.

- Review and approve all safety documentation associated with the water drill system including coordinating all required safety reviews, i.e., Nuclear Safety, Industrial Health and Safety, and Fire Protection Safety.

- Support the assessment of readiness, as required.

\subsection{TWRS RADIOLOGICAL CONTROL}
Manager:
R. J. Giordano
Engineer:
J. E. Pieper
ORG: 79700

- Perform radiological design reviews for implementation of ALARA engineering practices.

- Review and approve all radiological related safety documentation associated with the water drill system.

- Support the assessment of readiness, as required. 
- Provide Radiation Work Planners and Health Physics Technicians in support of field activities.

\subsection{TWRS QUALITY ASSURANCE}
Manager:
S. M. Byers
Engineer:
M. C. Tipps
ORG: 7B400

- Review and approve engineering documentation, as required.

- Perform design reviews of water drill system design including vendor drill head design.

- Prepare QA inspection plan for the vendor's water drill head and perform the necessary inspection activities to assure conformance to the procurement specification, including QA witness of vendor functional testing, as required.

- Perform design verification activities including witnessing qualification testing and inspecting as-built engineering drawings to ensure the documentation reflects the final system configuration.

- Support the assessment of readiness, as required.

\subsection{TWRS ENVIRONMENTAL PERMITS/POLICY}
Manager:
D. J. Carrell
Engineer:
C. J. Grando
ORG: 7B210

- Revise/update the NOC to authorize installation/operation of the water drill in tank $\mathrm{BY}-105$, as required.

\subsection{TWRS OPERATIONS TRAINING}
Manager:
3. M. Morris
Engineer:
T. C. Bender
ORG: 79620

- Prepare training materials and support training of Operations personnel. 


\subsection{NUMATEC HANFORD COMPANY EQUIPMENT DEVELOPMENT AND TESTING LABORATORIES (305 \& 306E FACILITIES)}

Manager:

Responsible Engineer:

ORG:
M. J. Schliebe

TBD

$8 \mathrm{C} 900$

- Provide fabrication support for the water drill system test fixtures, as required.

- Perform/support scoping tests using the test drill rig and qualification tests of the water drill system, and support training of TWRS Operations personnel, as required.

- Support equipment operation in the field during turnover to TWRS Operations, as required.

\subsection{DYNCORP HANFORD FABRICATION SERVICES}

Manager:

Fabrication Engineer:

ORG:

\author{
M. A. Butterworth \\ TBD \\ 52000
}

- Provide fabrication support for the riser interface and deployment mechanism components.

- Maintain a quality work package to allow final equipment QA inspection and acceptance. (typical contents: assembly instructions, weld records, material certifications; $\mathrm{QC}$ inspections, as required)

- Provide support for operational testing and training of Operations personnel.

\subsection{DYNCORP HANFORD CRANE \& RIGGING SERVICES}

$\begin{array}{ll}\text { Manager: } & \text { W. A. Ferree } \\ \text { Supervisor: } & \text { TBD } \\ \text { ORG: } & 55200\end{array}$

- Provide crane and rigging support for qualification testing of the water drill system, as required. 
HNF-3225 Rev. 0

\subsection{TWRS INTERIM STABILIZATION OPERATIONS}
Manager:
D. J. Saueressig
Supervisor:
M. N. Johnson
ORG:
79480

- Provide operations review of water drill system design and engineering documentation, as required.

- Provide personnel (supervisor, operators, etc.) for the qualification testing and training for the water drill system.

- Review and approve the installation/operation work instructions and work package for operation of the water drill system in tank BY -105 .

- Support the assessment or readiness, as required, and field operation of the water drill system.

\subsection{TWRS PRODUCTION CONTROL}

$\begin{array}{ll}\text { Manager: } & \text { J. A. Crawford } \\ \text { Planner: } & \text { TBD } \\ \text { ORG: } & 79220\end{array}$

- Prepare the work package including the installation/operation work instructions and assemble necessary support documentation (e.g., ALARA management work sheets, radiation work permits, job hazards analysis, etc).

\subsection{SCHEDULE AND COST ESTIMATE}

The schedule for the development of the water drill system is given in Appendix B This schedule assumes the project starts at the beginning of October 1998, following approval of this ETP and approval of task orders, as required. A summary of the primary activities are as follows.

Complete initial design review of support equipment Award contract for water drill head design/fabrication

Complete vendor functional testing of drill head

Complete fabrication of support equipment

Complete receipt inspection of vendor drill head

Complete qualification testing for water drill system

Complete operations training for water drill system Issue $\mathrm{ABU}$

Complete assessment of readiness for water drill system
$11 / 27 / 98$

$12 / 3 / 98$

$2 / 5 / 99$

$2 / 26 / 99$

$3 / 3 / 99$

$4 / 7 / 99$

$4 / 21 / 99$

$5 / 3 / 99$

$5 / 24 / 99$ 
The detailed cost estimate by organization for FY98 and FY99 is also provided in Appendix B. The total estimated costs without G\&A and CSP adders are $\$ 510 \mathrm{~K}$. With a $15 \%$ contingency, the cost estimate is $\$ 586 \mathrm{~K}$. The cost estimate is shown in man-hours and total dollars based on rates given in the appendix.

\subsection{CONFIGURATION MANAGEMENT}

The new documentation and hardware developed as part of this task will be maintained under configuration control in accordance with HNF-IP-0842, TWRS Administration Procedures, Volume IV, Section 3.5, "Engineering Documents" (LMHC 1996), and the project Hanford procedures identified as follows. All engineering documents to be maintained under configuration control shall be uniquely identified in accordance with HNF-PRO-227, Engineering Document Identification (HNF 1997a).

Supporting documents shall be assigned a unique identification number in accordance with HNF-PRO-439, Supporting Document Requirements (HNF 1997h). Using an engineering data transmittal (EDT) form, supporting documents will be reviewed, approved, and released in accordance with HNF-PRO-244, Engineering Data Transmittal Requirements (HNF 1997e), and HNF-PRO-317, Engineering Release and Approval Requirements (HNF 1997g). All engineering documents shall be submitted to Document Control Services for processing, release, and archival.

Engineering specifications shall be numbered, prepared, released, and maintained in accordance with HNF-PRO-241 (HNF 1997c). Vendor information will be compiled, identified, and controlled in accordance with HNF-PRO-444, Vendor Information Requirements (HNF 1997k). These documents are reviewed, approved, and released in the same manner as supporting documents.

As described in Section 3.5, the configuration of drawings of water drill system components to be fabricated on the Hanford Site will be under development control during fabrication in accordance with HNF-PRO-442 (HNF 1997j). Following fabrication, any changes/redines will be incorporated and drawings will be reviewed, approved, and released in accordance with HNF-PRO-242 (HNF 1997d). Drawings will be assigned a unique H-series number and the cognizant engineer with concurrence from the cognizant manager, will determine the classification for the drawings, i.e., essential, support, or general.

All subsequent changes to the engineering documents described above shall be controlled using ECNs in accordance with HNF-PRO-440 (HNF 1997i).

\subsection{QUALITY ASSURANCE}

All design documentation (drawings, functions \& requirements, procurement specifications, etc.) associated with this task shall be assigned approval designators by the 
cognizant engineer with concurrence from the cognizant manager in accordance with HNF-PRO233, Review and Approval of Documents (HNF 1997b). Those documents given an approval designator " $Q$ " shall be reviewed and approved by Quality Assurance. The final equipment inspection and qualification testing will be performed in accordance with WHC-CM-4-2, Quality Assurance Manual (WHC 1991).

\subsection{SAFETY AND AUTHORIZATION BASIS}

No changes to the existing authorization basis are anticipated associated with the installation/operation of the water drill system. A USQ screening/determination will be performed based on the preliminary design in accordance with HNF-IP-0842, Volume IV, Section 5.4, "Unreviewed Safety Questions" (LMHC 1998c). Following completion of the USQ screening and a conceptual design, a hazards assessment will be performed, if required, in accordance with HNF-PRO-704, Hazard and Accident Analysis Process (HNF 19970). This new UHP water drill is very similar to the UHP water drill that has been used several times for TVP installation, so it is very possible that a hazards assessment will not be required because the hazards associated with the new drill should have been previously analyzed. A USQ determination will then be completed, if required, based on the results of the USQ screening and hazards assessment to authorize installation/operation of the water drill system in the tank farms or to identify any need for modifying the $\mathrm{AB}$. The need for amending any other safety authorization documents, e.g., NOC, Clean Air Permit, etc., will also be evaluated. UHP water lancing operations are outside the bounds of the existing NOC based on a preliminary review. Therefore, the NOC must be revised, or, approval from the Washington State Department of Health (WDOH) may be obtained at a WDOH routine meeting if it can be shown that potential emissions from the new UHP water drill are bounded by the calculations in the existing NOC.

The hazards assessment will be the basis for the safety classification of the water drill system components. Safety classifications will be designated by the design authority with input from the cognizant engineer and concurrence from the cognizant manager in accordance with HNF-PRO-704 (HNF 1997o). If any of the components of the water drill system are designated as safety class or safety significant, the SEL will then be prepared/updated, as applicable, in accordance with HNF-IP-0842, Volume IV, Section 5.2, "Safety Equipment Lists" (LMHC 1998b). CGI forms will also be prepared, as applicable, in accordance with HNF-IP0842, Volume IV, Section 3.11 (LMHC 1998a).

All design documentation associated with this task shall be assigned approval designators by the cognizant engineer with concurrence from the cognizant manager in accordance with $\mathrm{HNF}$ PRO-233 (HNF 1997b). Those documents given an approval designator " $\mathrm{S}$ " shall be reviewed and approved by the appropriate TWRS safety organization. In addition, any radiological related safety documentation will be reviewed and approved by TWRS Radiological Control. 
HNF-3225 Rev. 0

\subsection{SYSTEMS ENGINEERING}

This task plan defines the work required to achieve the final objective of installing a saltwell screen in Tank BY-105. The interfaces between the participating organizations are also identified and therefore this task plan meets the requirements of the systems engineering function.

\subsection{CLOSEOUT COSTS}

If this project is terminated prior to completion, funds would be required to document the status of incomplete tasks and store incomplete work in a retrievable format or location. It is estimated that roughly $\$ 20 \mathrm{~K}-\$ 50 \mathrm{~K}$ would be required to perform closeout activities depending on the progress made toward project completion.

\subsection{REFERENCES}

Boger, R. M., 1997, “Engineering Task Plan,” DI-75200-002-00, Rev. 1, Lockheed Martin Hanford Company, Richland, Washington.

HNF, 1997a, Project Hanford Policies and Procedures Engineering Document Identification, HNF-PRO-227, Rev. 0, Fluor Daniel Hanford Inc., Richland, Washington.

HNF, 1997b, Project Hanford Policies and Procedures Review and Approval of Documents, HNF-PRO-233, Rev. 0, Fluor Daniel Hanford Inc., Richland, Washington.

HNF, 1997c, Project Hanford Policies and Procedures Engineering Specification Requirements, HNF-PRO-241, Rev. 0, Fluor Daniel Hanford Inc., Richland, Washington.

HNF, 1997d, Project Hanford Policies and Procedures Engineering Drawing Requirements, HNF-PRO-242, Rev. 1, Fluor Daniel Hanford Inc., Richland, Washington.

HNF, 1997e, Project Hanford Policies and Procedures Engineering Data Transmittal

Requirements, HNF-PRO-244, Rev. 0, Fluor Daniel Hanford Inc., Richland, Washington.

HNF, 1997f, Project Hanford Policies and Procedures Control of Purchased Items and Services,

HNF-PRO-268, Rev. 0, Fluor Daniel Hanford Inc., Richland, Washington.

HNF, 1997g, Project Hanford Policies and Procedures Engineering Release and Approval Requirements, HNF-PRO-317, Rev. 0, Fluor Daniel Hanford Inc., Richland, Washington.

HNF, 1997h, Project Hanford Policies and Procedures Supporting Document Requirements, HNF-PRO-439, Rev. 0, Fluor Daniel Hanford Inc., Richland, Washington. 
HNF, 1997i, Project Hanford Policies and Procedures Engineering Document Change Control Requirements, HNF-PRO-440, Rev. 1, Fluor Daniel Hanford Inc., Richland, Washington.

FNF, 1997j, Project Hanford Policies and Procedures Development Control Requirements, HNF-PRO-442, Rev. 0, Fluor Daniel Hanford Inc., Richland, Washington.

HNF, 1997k, Project Hanford Policies and Procedures Vendor Information Requirements, HNFPRO-444, Rev. 0, Fluor Daniel Hanford Inc., Richland, Washington.

HNF, 19971, Project Hanford Policies and Procedures Design Verification Requirements, HNFPRO-445, Rev. 0, Fluor Daniel Hanford Inc., Richland, Washington.

HNF, 1997m, Project Hanford Policies and Procedures Testing Requirements, HNF-PRO-446, Rev. 1, Fluor Daniel Hanford Inc., Richland, Washington.

HNF, 1997n, Project Hanford Policies and Procedures Procurement of Safety Class Items and Management of Spares, HNF-PRO-447, Rev. 1, Fluor Daniel Hanford Inc., Richland, Washington.

HNF, 1997o, Project Hanford Policies and Procedures Hazard and Accident Analysis Process, HNF-PRO-704, Rev. 0, Fluor Daniel Hanford Inc., Richland, Washington.

HNF, 1998, Project Hanford Policies and Procedures Radiological Design Review Process, HNF-PRO-1622, Rev. 0, Fluor Daniel Hanford Inc., Richland, Washington.

LMHC, 1996, TWRS Administration, HNF-IP-0842, Volume IV, Section 3.5, Rev. 1, "Engineering Documents," Lockheed Martin Hanford Corporation, Richland, Washington.

LMHC, 1998a, TWRS Administration, HNF-IP-0842, Volume IV, Section 3.11, Rev. 1, "Replacement Item Evaluation, Commercial Grade Item Dedication and Upgrade," Lockheed Martin Hanford Corporation, Richland, Washington.

LMHC, 1998b, TWRS Administration, HNF-IP-0842, Volume IV, Section 3.12, Rev. 1b, "Acceptance of Structures, Systems, and Components for Beneficial Use," Lockheed Martin Hanford Corporation, Richland, Washington.

LMHC, 1998c, TWRS Administration, HNF-IP-0842, Volume IV, Section 5.4, Rev. 10g, "Unreviewed Safety Questions", Lockheed Martin Hanford Corporation, Richland, Washington.

LMHC, 1998d, TWRS Administration, HNE-IP-0842, Volume IV, Section 5.2, Rev. 1a, "Safety Equipment Lists," Lockheed Martin Hanford Corporation, Richland, Washington.

WHC, 1991, Quality Assurance Manual, WHC-CM-4-2, latest revision, Westinghouse Hanford Company, Richland, Washington. 
HNF-3225 Rev. 0

APPENDIX A - ACCEPTANCE FOR BENEFICIAL USE FORM

A-1 
HNF-3225 Rev. 0

ACCEPTANCE FOR BENEFICIAL USE (ABU)

1. Document Title: ENGINEERING TASK PLAN FOR THE DEVELOPMENT OF A HIGH PRESSURE WA'FER DRILL SYSTEM FOR BY-105 SALTWELL SCREEN INSTALLATION

3. Document No.

HNF-3225

\begin{tabular}{|l|l|} 
& NA \\
\hline
\end{tabular}

9. Final $A B U()$

Partial ABU ( )
2. Engineering Task No. TBD

6. System/ Bldg/Facility 200General

7.Equip/ Component No.

BY-105

Water Drill

System

10. ATP Rerun Required

( ) Yes

( ) No

11. Description of Work

12. Description of Work to be Completed

See Section 3.1 and 3.2 of HNF -3225
13.

Scineduted

Completion

Date

$5 / 3 / 99$
14

Responsibility

for Completion

GA Ritter

15. Impact on Operations/Safety

Water drill system installation/operation in accordance with the Authorization Basis and State operating permits. 


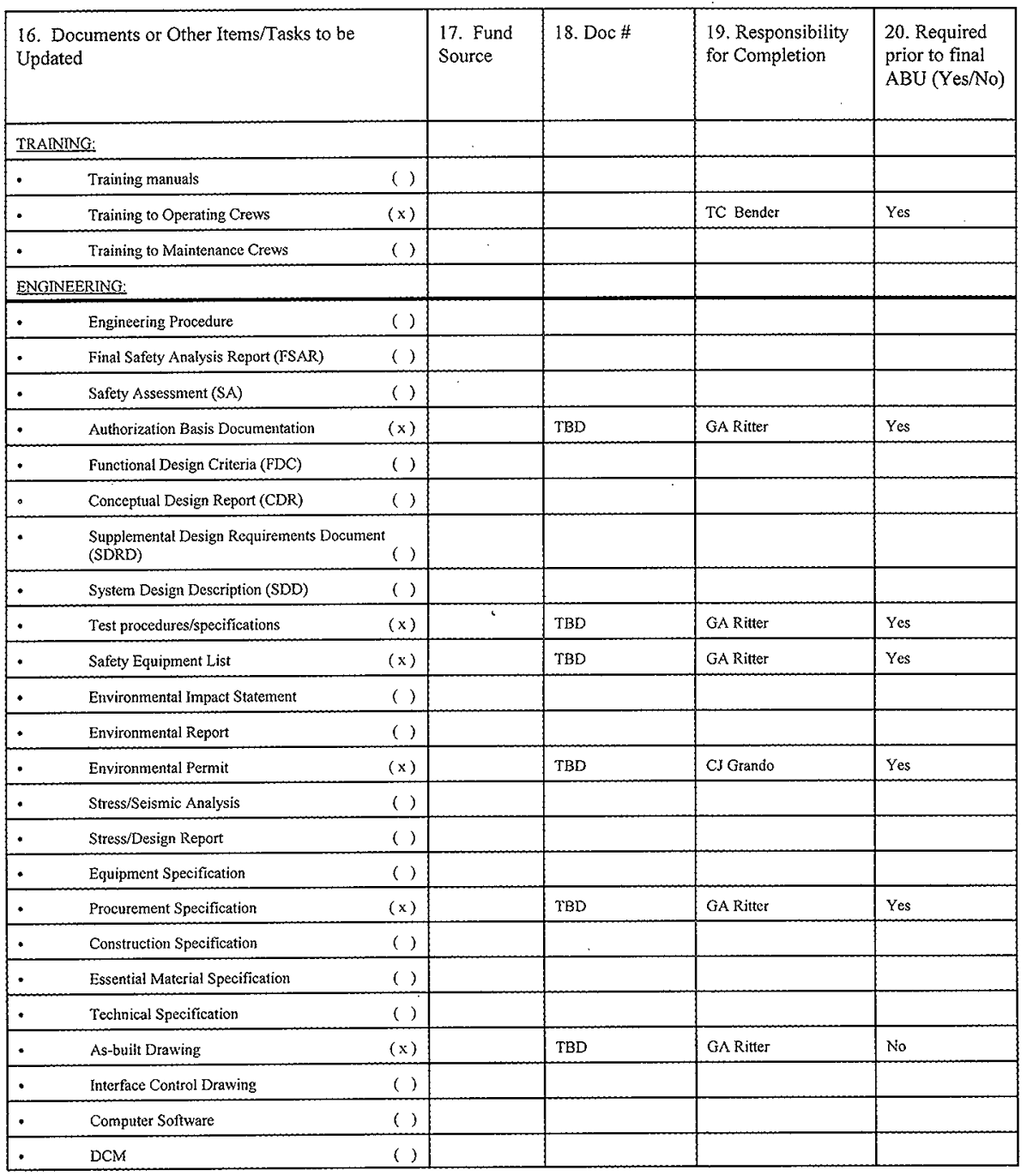


HNF-3225 Rev. 0

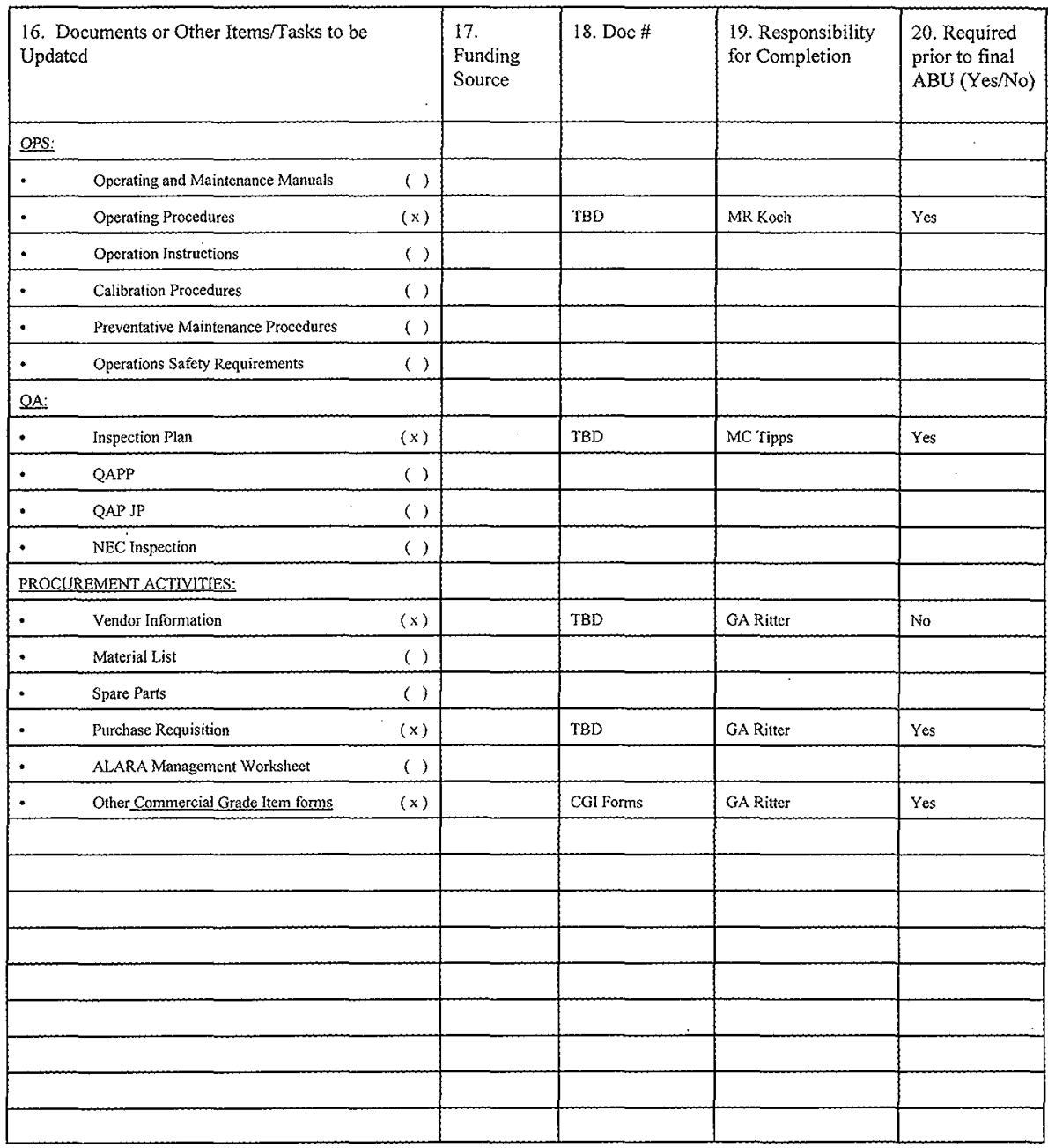


HNF-3225 Rev. 0

OPERATIONS AND ENGINEERING

$\mathrm{Cog}$ /Field Engineer $\mathrm{CB} M c V e y$

Cog/Field Mgr. MR Koch

QA MC Tipps

Safety LS Krogsrud

Radiological Control JE Pieper

Projects Stabilization

Modification Projects

Interim Stabilization Ops DJ Saueressig

Design Engineer/Agent GA Ritter

Design Authority PF Kison 
HNF-3225 Rev. 0

APPENDIX B - SCHEDULE AND COST ESTIMATE

B-1 
HNF-3225 Rev. 0

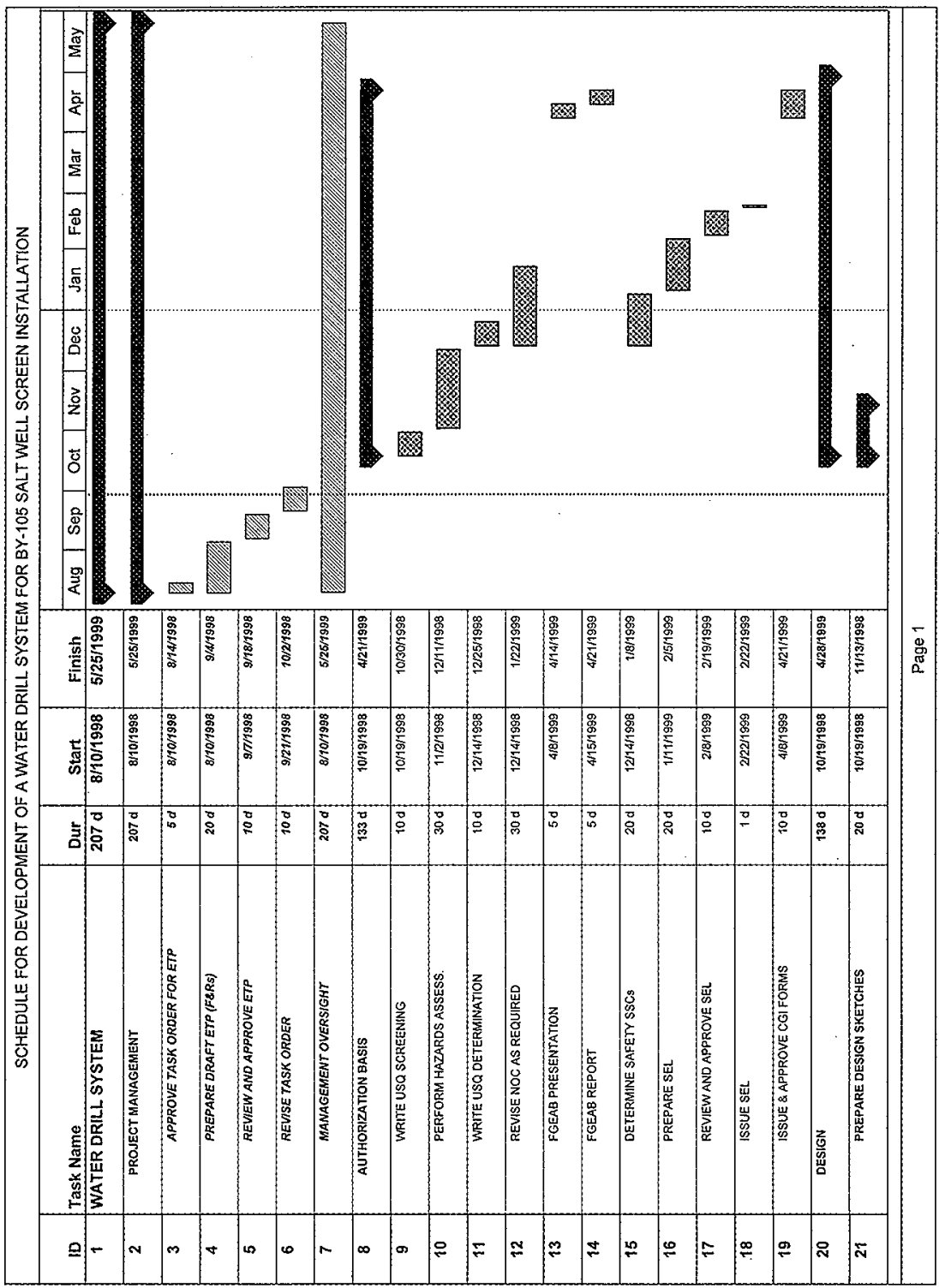

B-2 


\begin{tabular}{|c|c|c|c|c|c|c|c|c|c|c|c|c|c|c|}
\hline \multicolumn{15}{|c|}{ SCHEDULE FOR DEVELOPMENT OF A WATER DRILL SYSTEM FOR BY-105 SALT WELL SCREEN INSTALLATION } \\
\hline ID & Task Name & Dur & Start & Finish & Aug & Sep & Oct & Nov & Dec & Jan & Feb & Mar & Apr & May \\
\hline 22 & DEPLOYMENT MECHANISM & $20 \mathrm{~d}$ & $10 / 19 / 1998$ & $111 / 13 / 1998$ & & & & & & & & & & \\
\hline 23 & TANK INTERFACE & 200 & 10/19/1998 & $11 / 13 / 1998$ & & & & & & & & & & \\
\hline 24 & IDENTIFY AUXILLARY EQUIIIP. & $20 \mathrm{~d}$ & $10 / 19 / 1998$ & $11 / 13 / 1998$ & & & & & & & & & & \\
\hline 25 & WATER SOURCE & 200 & 10/19/1988 & $1 t / 13 / 1998$ & & & & & & & & & & \\
\hline 26 & ELECTRICAL POWER & 200 & 10/19/1998 & $11 / 13 / 1998$ & & & & & & & & & & \\
\hline 27 & HOISTING REOMTS & 200 & 10/19/1998 & $11 / 13 / 1998$ & & & & & & & & & & \\
\hline 28 & PERFORM INITIAL DESIGN REVIEW & 100 & 11/16/1998 & $11 / 27 / 1998$ & & & & 展 & & & & & & \\
\hline 29 & PERFORM FINAL DESIGN REVIEW & $10 d$ & $2 / 811999$ & $2 / 19 / 4999$ & & & & & & & 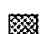 & & & \\
\hline 30 & AS-BUILO DRAWNAS & 15ם & 4/8/1999 & $4 / 28 / 1999$ & & & & & & & & & & \\
\hline 31 & PROCUREMENT OF WATER JET & $128 d$ & $10 / 5 / 1998$ & $3 / 31 / 1999$ & & & & & & & & & & \\
\hline 32 & WRITE PROCUREMENT SPEC. & $10 d$ & 10/5/1998 & 10/16/1998 & & & & & & & & & & \\
\hline 33 & REVEW AND APPROVE SPEC. & $10 d$ & 10/19/1998 & 10/30/1998 & & & & & & & & & & \\
\hline 34 & ISSUE PROC. SPEC. & $1 d$ & $11 / 2 / 1998$ & $11 / 21998$ & & & & & & & & & & \\
\hline 35 & WRITE P.O. & $3 d$ & $11 / 3 / 1998$ & $11 / 5 / 1998$ & & & & 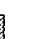 & & & & & & \\
\hline 36 & ISSUERFP & 100 & $11 / 6 / 1998$ & 11/19/1998 & & & & & & & & & & \\
\hline 37 & EVALUATE PROPOSALS & $5 d$ & 11/20/1998 & 11/26/1998 & & & & V & & & & & & \\
\hline 38 & PLACE CONTRACT & $5 d$ & 11/27/7998 & $12 / 3 / 2998$ & & & & & & & & & & \\
\hline 39 & VENDOR OESIGN & 158 & $124 / 4998$ & 12/24/1998 & & & & & 勿级 & & & & & \\
\hline 40 & REVEWVENDOR DESIGN & $5 d$ & $12 / 25 / 1998$ & $12 / 31 / 1998$ & & & & & & & & & & \\
\hline 41 & APPROVE VENDOR OES/GN & 10 & 1/1/1999 & $1 / 7 / 1999$ & & & & & & & & & & \\
\hline 42 & VENDOR FABRICATION & 200 & 7/4/9999 & $1 / 29 / 1999$ & & & & & & & & & & \\
\hline & & & & Page 2 & & & & & & & & & & \\
\hline
\end{tabular}


HNF-3225 Rev. 0

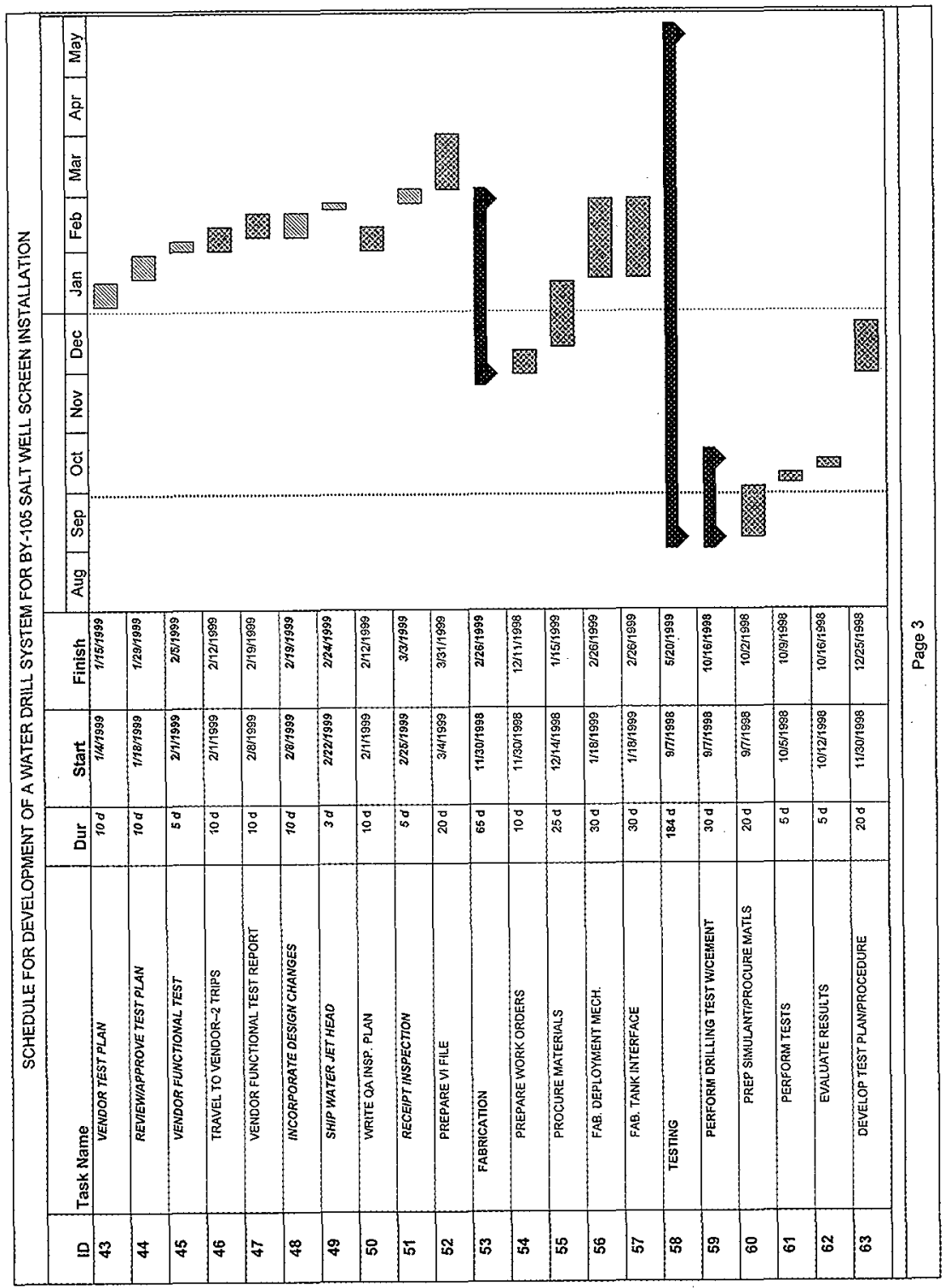


HNF-3225 Rev. 0

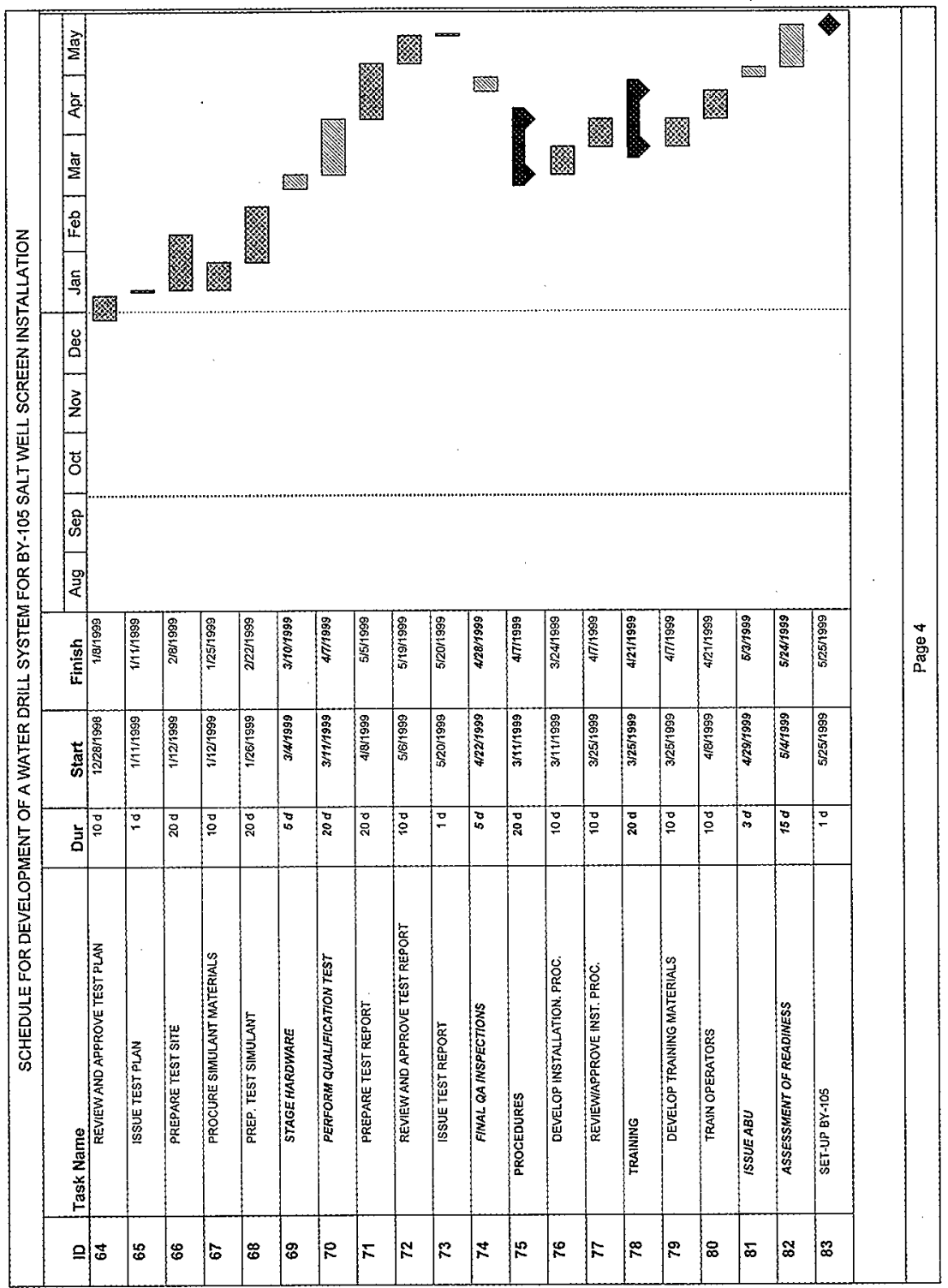


HNF-3225 Rev. 0

高就

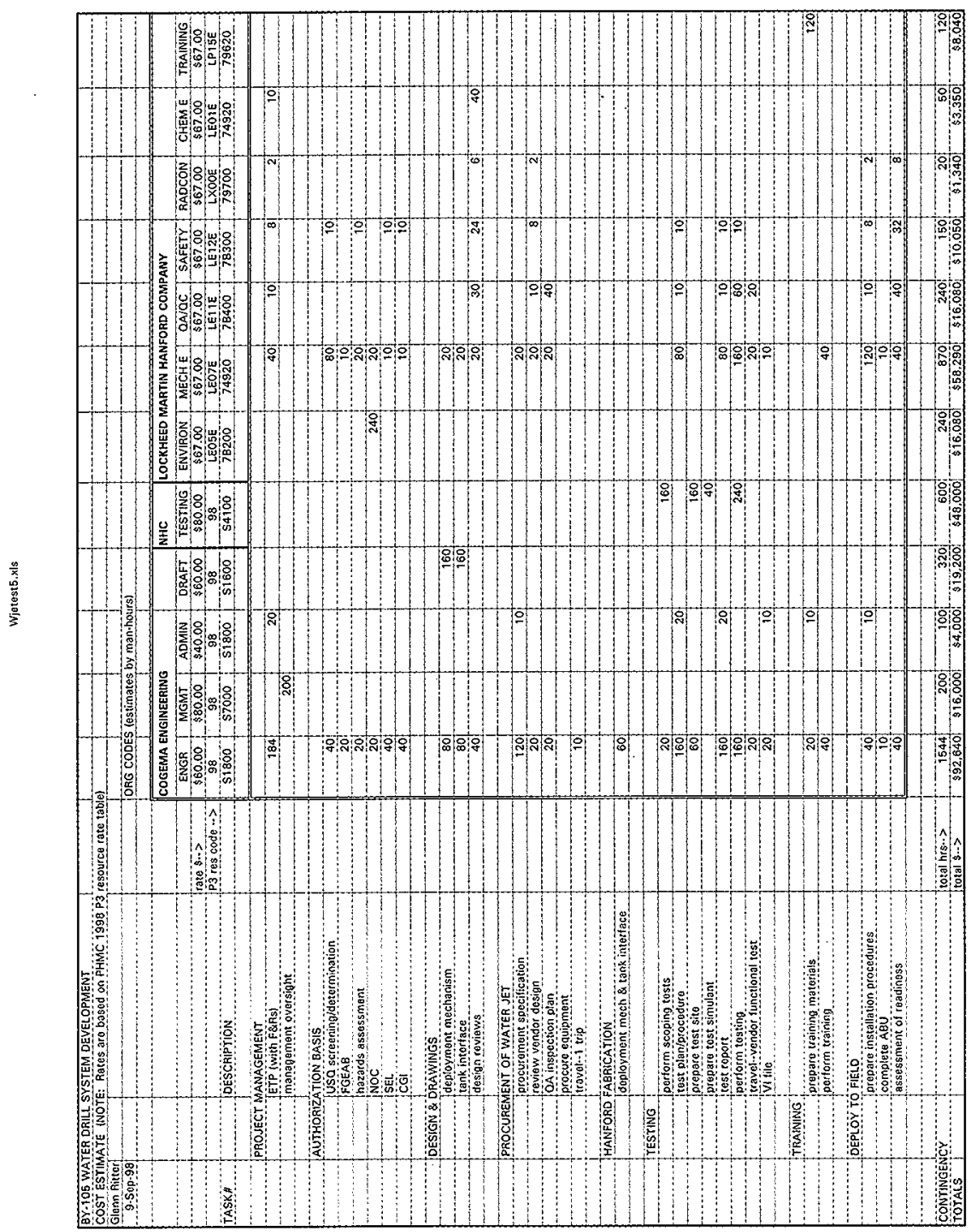


HNF-3225 Rev. 0

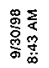

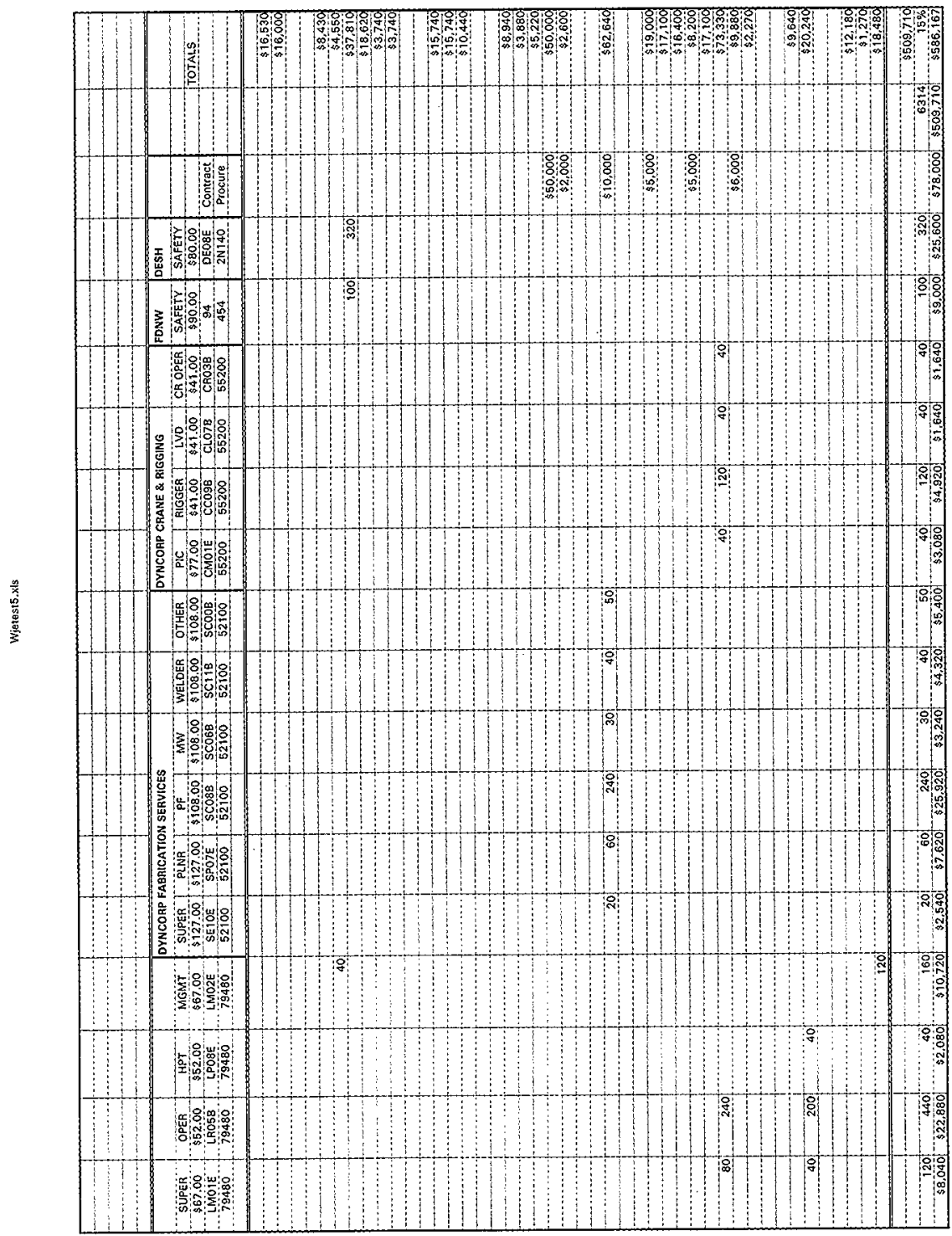

B-7 